\title{
Morphological Characteristics and Genetic Variability of Trichoderma spp. From Conventional Cotton Crop Soils in Federal District, Brazil
}

\author{
Daniel Diego C. Carvalho ${ }^{1}$, Peter W. Inglis ${ }^{2}$, Zilá R. de Ávila², Irene Martins ${ }^{2}$, Paulo Henrique P. C. Muniz \\ \& Sueli C. M. de Mello ${ }^{2}$ \\ ${ }^{1}$ Universidade Estadual de Goiás, Câmpus Ipameri, Ipameri, Goiás, Brazil \\ ${ }^{2}$ Embrapa Recursos Genéticos e Biotecnologia, Brasília, Distrito Federal, Brazil \\ Correspondence: Sueli C. M. De Mello, Prédio de Controle Biológico 1, Embrapa Recursos Genéticos e \\ Biotecnologia, Parque Estação Biológica, W5 Norte Final, Brasília, Distrito Federal, Brazil. E-mail: \\ sueli.mello@embrapa.br
}

Received: April 15, 2018

Accepted: May 24, $2018 \quad$ Online Published: July 15, 2018

doi:10.5539/jas.v10n8p146

URL: https://doi.org/10.5539/jas.v10n8p146

\begin{abstract}
This study aimed to characterize 41 isolates of Trichoderma from conventional cotton crops soils as the morphological and cultural characteristics and to investigate polymorphism, using RAPD markers. The most common group comprised $80.6 \%$ of the isolates and was identified as a strain of Trichoderma harzianum. The others species were T. aureoviride (7.3\%), T. viride (7.3\%) and T. crassum (4.8\%). The four species were morphologically distinct in the evaluated characteristics such as colony appearance and mycelium growth rate after being grown on malt extract agar (MEA), potato dextrose agar (PDA) and oatmeal agar (OA) media, and also in shape of conidia, phialides, and conidiophores. The four species were separated in a dendogram, after using RAPD markers. Besides, RAPD was efficient in demonstrating the high intraspecific genetic variation among isolates of two species (T. harzianum and T. aureoviride).
\end{abstract}

Keywords: biocontrol agent, molecular analysis, mycology, soil biology

\section{Introduction}

Trichoderma spp. is natural soil fungi, which occurs in the rhizospheric and non-rhizospheric soils (Rai et al., 2016). They are also often found associated with rotting wood, with strains that are efficient producers of industrial enzymes and therefore economically important (Druzhinina \& Kubicek, 2005). Most species from this genus are opportunistic, avirulent plant symbionts, and some of them function as parasites and antagonists of many plant pathogens (Vinale et al., 2008). In Brazil, native Trichoderma spp. were found in the rhizosphere of soybean (Almeida et al., 2001), cucumber and tomato (Lisboa et al., 2007; Ethur et al., 2008). The knowledge of the presence and distribution of Trichoderma spp. in cultivated soils is important to elaborate an effective strategy for biological control of soil-borne pathogens (Ethur et al., 2008), using these fungi. This strategy is beneficial for the environment in the long term, since it minimizes the use of chemical pesticides in plant disease management.

Brazilian isolates of Trichoderma have been characterized based on genetic and morphological criteria (Sharma et al., 2009). Specifically, DNA markers have become a powerful tool to study taxonomy and molecular analysis of organisms. The random amplified polymorphic DNA (RAPD) has been used to allows quick assessment of genetic variability in various species, specially to study inter and intraspecific variability among isolates of several species of Trichoderma used in biological control (Sharma et al., 2009; Pandya et al., 2017). Besides, molecular characterization provides an immense source of data that can assist to the scientists in the study of identity, relatedness, diversity and selection of proper candidates for biological control (Gajera \& Vakharia, 2010).

Assessment of genetic relatedness among antagonistic Trichoderma spp. using fingerprint techniques, such as RAPD, is important to elucidate the diversity in different crop rhizospheres and to characterize the biocontrol agents for registration and patenting (Shanmugam et al., 2008; Ranil et al., 2017).

Recently, the potential of Trichoderma isolates as biocontrol agents of soil-borne pathogens was observed in our laboratory by Carvalho et al. $(2014,2015)$. Aiming to follow up the works mentioned, the objectives of this 
study were to characterize Trichoderma spp. from conventional cotton crop soils based on morphological and cultural characteristics and to investigate polymorphism, using RAPD markers.

\section{Method}

\subsection{Fungal Isolates}

Soil samples were collected from conventional cotton crops (cv. FM 975 WS) throughout the Federal District, Brazil (15 49'03.68" S; 47 34'42.67" W; 978 m; climate classification Aw according Köppen). From each sample, $1 \mathrm{~g}$ of soil (Red latosol) was removed and added to $9 \mathrm{~mL}$ of $0.05 \%$ Tween solution. Subsequently, serial dilutions were made according to Dhingra and Sinclair (1981) using modified Martin's medium. All micromorphological data (conidia, conidiophores and phialides), descriptions and identification of purified isolates were carried out according to Gams and Bisset (1998). The isolates were stored in sterile distilled water (Castellani) at $10^{\circ} \mathrm{C}$ and in mineral oil at $15{ }^{\circ} \mathrm{C}$ and integrated in the collection of Biological Control Fungi of Embrapa Recursos Genéticos e Biotecnologia, Brasília, Distrito Federal, Brazil.

\subsection{Micromorphological and Cultural Observations}

Cultural characteristics such as colony appearance and sporulation pattern were examined from cultures grown in darkness at $25^{\circ} \mathrm{C}$ for $96 \mathrm{~h}$ on $2 \%$ malt extract agar (MEA, $30 \mathrm{~g} \mathrm{~L}^{-1}$ of malt extract, $5 \mathrm{~g} \mathrm{~L}^{-1}$ of bacteriologic peptone and $15 \mathrm{~g} \mathrm{~L}^{-1}$ of agar; $\mathrm{pH}$ 5.4) and potato dextrose agar (PDA, $\mathrm{pH}$ 5.6). Cultures were also grown under $12 \mathrm{~h}$ of photoperiod (Philips daylight fluorescent lamp, 20W, TLT, 75RS) at $25^{\circ} \mathrm{C}$ during $96 \mathrm{~h}$ on PDA and Oatmeal agar $\left(\mathrm{OA}, 20 \mathrm{~g} \mathrm{~L}^{-1}\right.$ of agar and $1 \mathrm{~L}$ of filtered oat broth obtained from autoclaved broth containing $20 \mathrm{~g}$ $\mathrm{L}^{-1}$ of oat flakes, $\mathrm{pH} 7.2$ ). Radial growth rates were daily measured at $25^{\circ} \mathrm{C}$ using MEA and PDA (a) (darkness), PDA (b), and OA (12 h of fluorescent light) as culture medium. The Petri dishes incubated in darkness were exposed to light only on those occasions when they were examined. For analysis of colony characteristics and radial growth rate, agar plugs $(5 \mathrm{~mm})$ were taken from the actively growing margin of the culture grown for 3 days on PDA. Removed agar plugs were placed at $5 \mathrm{~mm}$ distant from the edge of $84 \mathrm{~mm}$ Petri dish. Part of mycelium developed at $25^{\circ} \mathrm{C}$ on PDA (darkness) was removed from the colonies at seven days of incubation in order to prepare permanent microscope slides. Cotton blue was used for the examination and measurements of conidia, conidiophores and phialides (30 measurements for each structure). Structures were measured using an AXIOPHOT Carl Zeiss light photomicroscope. The experiments were carried out in triplicate and the radial growth data at 4 days of growth was submitted to the Scott-Knott test $(\mathrm{P} \leq 0.05)$ using SISVAR 5.3 software (Ferreira, 2011).

\subsection{Intron Splice Site PCR Fingerprinting}

PCR-based fingerprinting using fungal intron splice site primers: EI1, CTGGCTTGGTGTATGT; EI2, CTGGCTTGCTACATAC; LA1, GCGACGGTGTACTAAC; LA2, CGTGCAGGTGTTAGTA, was carried out essentially as described previously (Inglis et al., 2005; Barros Lopes et al., 1996), using 20 ng fungal DNA, extracted from mycelium using a CTAB-based method (Rogers \& Bendich, 1988). PCR products were resolved by electrophoresis on $1.5 \% \mathrm{w} / \mathrm{v}$ agarose gels and bands detected by ethidium bromide staining.

Well-resolved amplified PCR products were scored $(1=$ present; $0=$ absent $)$ as binary characters, and data combined (73 total characters). Data was then analyzed using Paup* v4.0 (Swofford, 2003). A pairwise distance matrix was calculated according to Nei and Li (1979), which considers only the joint presence of a character as an indication of similarity. Clustering of the similarity data was done using the unweighted pairgroup method, arithmetic mean (UPGMA; Sneath \& Sokal, 1973) and an unrooted dendogram produced. Branch support was calculated using 1000 bootstrap pseudoreplicates (Felsenstein, 1985), within Paup*.

\section{Results}

\subsection{Trichoderma spp. Isolated From Conventional Cotton Crops Soils}

A total of 41 isolates of Trichoderma spp. were isolated from soils of conventional cotton crops in the Federal District, Brazil. Based on cultural, morphological and genetic characteristics, the isolates were divided into four groups. According to descriptions published by Gams and Bissett (1998), each group was identified as Trichoderma harzianum (80.6\%), T. aureoviride (7.3\%), T. viride (7.3\%) and T. crassum (4.8\%).

\subsection{Cultural Characterisitics}

For show cultural characteristics, an isolate of each species was elected. In this sense, T. harzianum had CEN240, T. viride had CEN260, T. aureoviride had CEN265, and T. crassum had CEN266. Thus, colony appearance of the four different species grown for 4 days at $25^{\circ} \mathrm{C}$ on MEA and PDA (darkness), PDA, and OA (12 h of fluorescent light) is showed in Figure 1. 
On MEA, T. harzianum sporulated only in the vicinity of the point of inoculation, while isolates from other species showed no formation of spores in this medium. T. aureoviride showed uniformly flat and velvety colonies, with aerial mycelium consisting of short hyphae in one lawn over the colony. T. crassum also had colonies in uniform lawn, but lower than T. aureoviride and T. viride.

On PDA (a), T. harzianum showed effuse to dense conidiation over the center of colonies. T. viride grew as one irregular lawn with diluted and widely spread conidiation. T. aureoviride exhibited a dense lawn of mycelium in respect to T. tomentosum. Apparently, no conidiation could be verified on the surface of the colonies of these two species, but was observed through examination of microscopic slides prepared after seven days of cultivation.

On PDA (b), T. harzianum formed 3-4 concentric rings with dense conidial production. T. viride showed no sporulation around the inoculum point, but dense mycelia toward the edge. Conidial production was not observed in colonies of $T$. aureoviride, but effuse yellow pigment occurred. $T$. crassum exhibited slightly cottony colonies with conidiation aggregated in tiny $(<1 \mathrm{~mm})$ flat pulverulence formed around the point of inoculation.

In $\mathrm{OA}$, three concentric rings with conidial production were observed in colonies of T. harzianum, but at a lower intensity than in PDA (b) medium. T. viride and T. atroviride failed to produce conidia, and only few irregular mycelia and a uniform lawn of mycelium were observed, respectively. Just as observed on PDA (b), T. atroviride also produced yellow pigment on OA under $12 \mathrm{~h}$ darkness $/ 12 \mathrm{~h}$ light intervals. Similar colony characteristics of $T$. tomentosum grown on PDA (b) were also observed when the fungus was grown on OA.

After four days of growth under fluorescent light incidence on PDA and OA, statistical analysis shown difference regarding the radial growth rate between $T$. viride CEN260 and T. crassum CEN266 (statistically similar; $8.4 \mathrm{~cm}$ on PDA b; 8.0 and $7.7 \mathrm{~cm}$ on OA) as well between T. harzianum CEN240 (7.5 $\mathrm{cm}$ and $6.5 \mathrm{on}$ PDA $\mathrm{b}$ and OA, respectively) and T. aureoviride CEN265 (5.8 and 5.1 on PDA b and OA, respectively), which were statistically different themselves and in respect to the other two species (Figure 2). Under darkness and on PDA, T. viride grew on all areas of the Petri dish by the third day of cultivation. On MEA, T. harzianum (6.1 cm) was statistically different from the other three species $(7.6$ to $8.4 \mathrm{~cm})$, which were statistically similar.

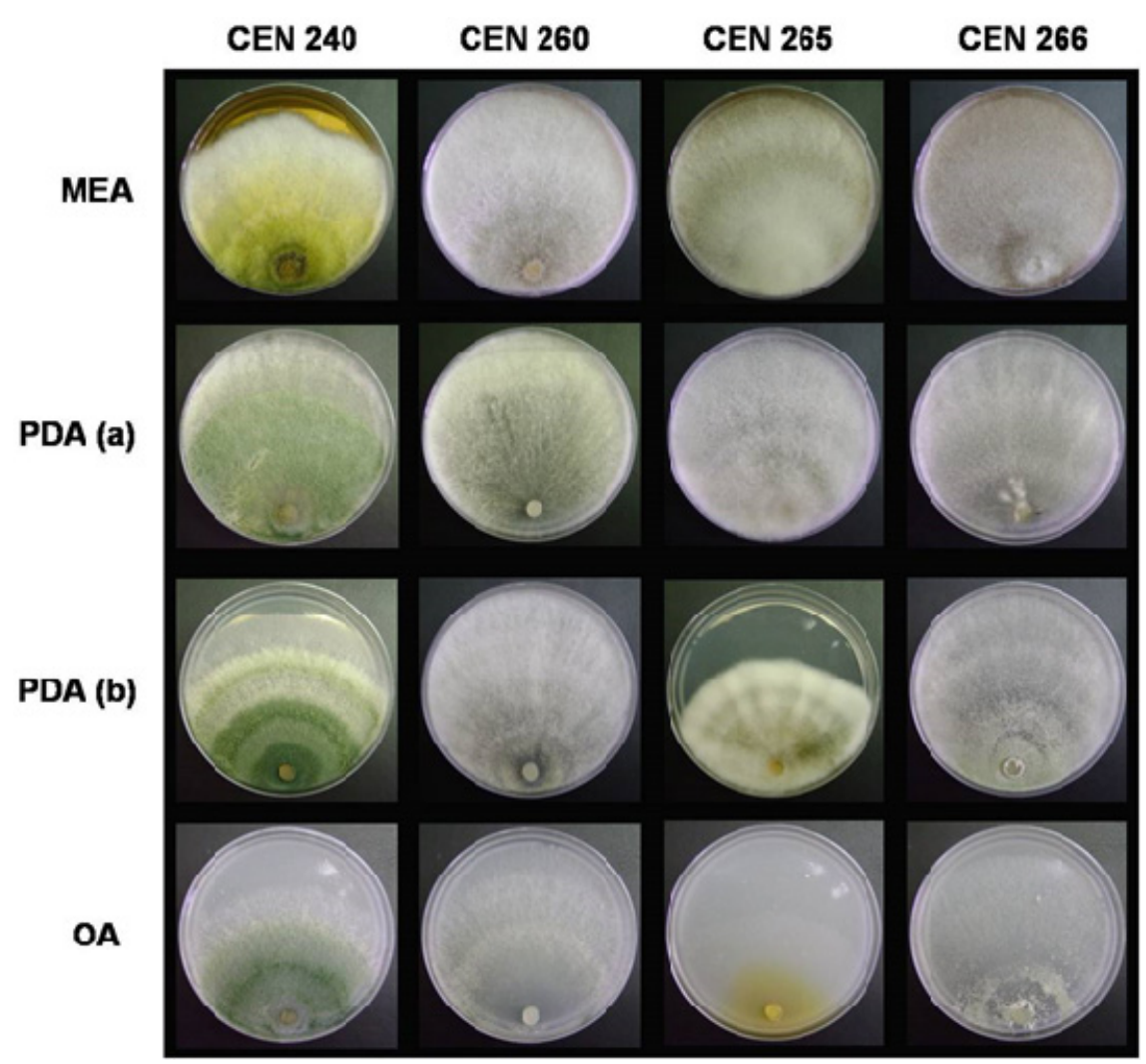

Figure 1. Colony appearance of four different species of Trichoderma grown for $96 \mathrm{~h}$ at $25^{\circ} \mathrm{C}$ on MEA and PDA (darkness) and PDA and OA (12 h of fluorescent light). T. harzianum (CEN240), T. viride (CEN260), T. aureoviride (CEN265) and T. crassum (CEN266) 


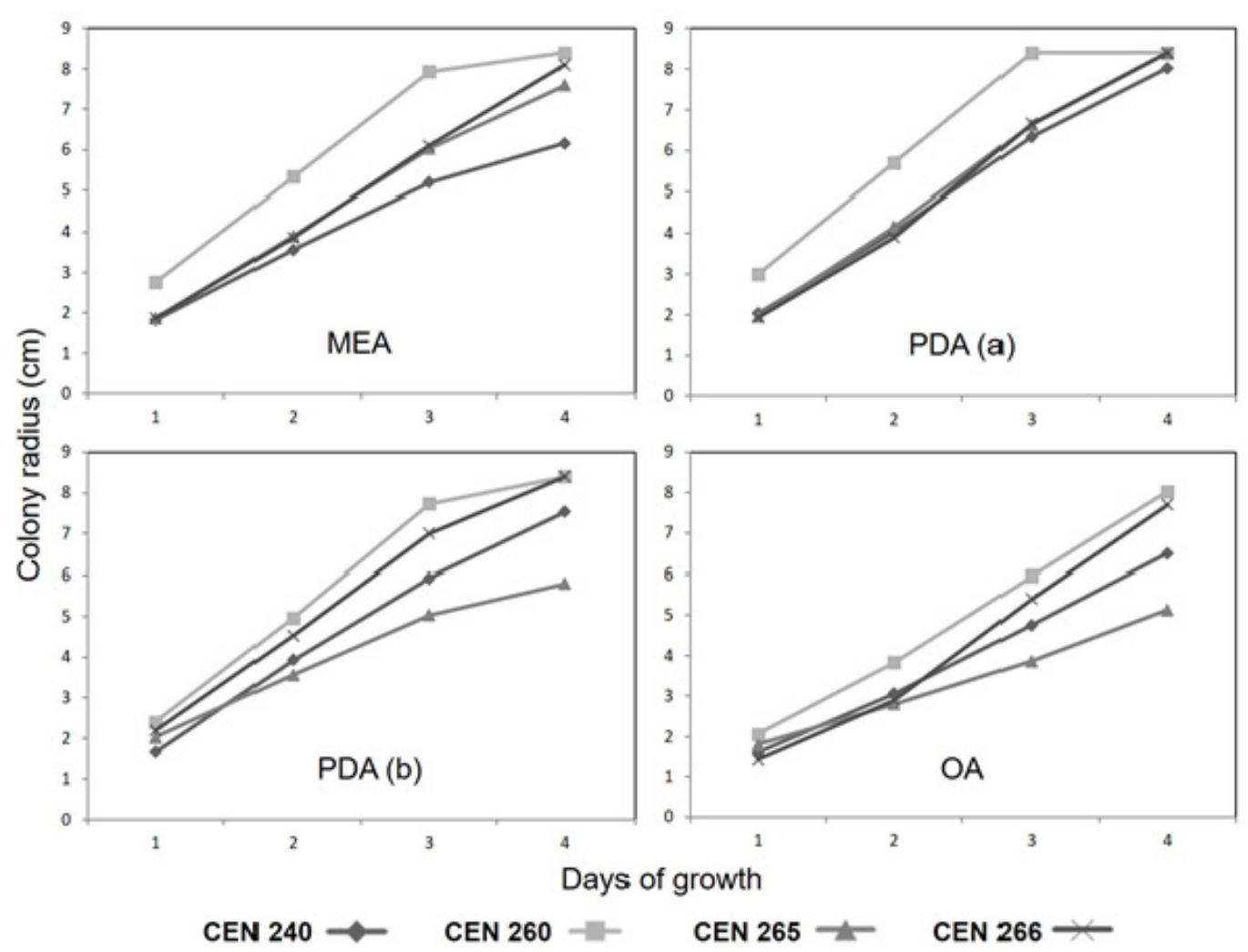

Figure 2. Radial growth rate of four different species of Trichoderma grown for 4 days at $25^{\circ} \mathrm{C}$ on MEA and PDA (a) (darkness) and PDA (b) and OA (12 h of fluorescent light). T. harzianum (CEN240), T. viride (CEN260), T. aureoviride (CEN265) and T. crassum (CEN266). Mean standard error was 0.15 for MEA, PDA (a) and PDA

(b) and 0.2 for $\mathrm{OA}$

\subsection{Micromorphological Characteristics}

Differences among the four species in terms of micromorphological features are described in Table 1. Conidia of T. harzianum were subglobose to ovoidal and had $\mathrm{L} / \mathrm{W}$ ratio of 1.11 . Conidia of $T$. viride and $T$. aureoviride were subglobose with L/W ratio of 1.16 and 1.64, respectively. Conidia of $T$. crassum were broadly ellipsoidal with $\mathrm{L} / \mathrm{W}$ ratio of 1.34. Phialides of $T$. harzianum tended to be shorter, with a length of $5.1 \mu \mathrm{m}$, while for the other groups a variation was found from 7.2 to $10.6 \mu \mathrm{m}$. T. viride showed conidiophores comprising a flexuous fertile central axis, with lateral branches paired and typically arising at an angle near $90^{\circ}$. Its phialides were cylindrical to swollen in the middle, straight and with an elongated neck. Phialides of T. aureoviride and T. crassum had one $\mathrm{L} / \mathrm{W}$ ratio of 3.86 and 2.92 , respectively. 
Table 1. Micromorphological characteristics of Trichoderma spp. isolated from conventional cotton crop soils. Federal District, Brazil

\begin{tabular}{|c|c|c|c|c|c|c|}
\hline \multirow{2}{*}{ Species } & \multicolumn{3}{|c|}{ Phialide } & \multicolumn{3}{|c|}{ Conidia } \\
\hline & Shape & Size $(\mu \mathrm{m})$ & $\mathrm{L} / \mathrm{W}^{* *}$ & Shape & Size $(\mu \mathrm{m})$ & $\mathrm{L} / \mathrm{W}^{* *}$ \\
\hline T. harzianum & Ampulliform & $\begin{array}{l}4.0-6.6 \times 1.7-3.1 \\
(5.1 \times 2.3)^{*}\end{array}$ & 2.23 & subglobose to ovoidal & $\begin{array}{l}2.7-3.1 \times 2.5-3.0 \\
(3.0 \times 2.7)\end{array}$ & 1.11 \\
\hline T. viride & $\begin{array}{l}\text { cylindrical to swollen in the } \\
\text { middle, straight and with an } \\
\text { elongated neck }\end{array}$ & $\begin{array}{l}5.0-12.5 \times 1.8-3.0 \\
(7.2 \times 2.4)\end{array}$ & 3.16 & subglobose & $\begin{array}{l}3.0-4.1 \times 2.6-3.5 \\
(3.5 \times 2.9)\end{array}$ & 1.16 \\
\hline T. aureoviride & $\begin{array}{l}\text { straight, tapering slightly from } \\
\text { base to tip }\end{array}$ & $\begin{array}{l}8.5-14.0 \times 2.0-3.9 \\
(10.6 \times 2.8)\end{array}$ & 3.86 & subglobose & $\begin{array}{l}3.5-5.0 \times 2.5-3.0 \\
(4.5 \times 2.8)\end{array}$ & 1.64 \\
\hline T. crassum & $\begin{array}{l}\text { short, ampulliform, base } \\
\text { constricted, swollen in the } \\
\text { middle, attenuate at the tip }\end{array}$ & $\begin{array}{l}5.0-11.0 \times 2.0-3.6 \\
(8.1 \times 2.9)\end{array}$ & 2.92 & broadly ellipsoidal & $\begin{array}{l}3.0-4.5 \times 2.4-3.5 \\
(3.8 \times 2.8)\end{array}$ & 1.34 \\
\hline
\end{tabular}

Note. ${ }^{*}$ Average values of 30 unities of each character; ${ }^{* *}$ Ratio of length to width. Values among parentheses indicat average values.

\subsection{Random Amplified Polymorphic DNA (RAPD)}

After RAPD analysis, it was verified three major groups with the highest similarity $(>60 \%)$ among the isolates (Figure 3). The four species of this study were separated in RAPD analysis, supporting the morphologic and cultural characteristics. The group containing T. crassum (CEN266 and CEN252) isolates clustered with $T$. harzianum isolates, showing approximately $90 \%$ similarity. In other cluster, T. viride (CEN221, CEN204 and CEN260) was separated from the other species. Doubtless, T. viride was the most distant group, affording $80 \%$ distanced from the others. Although T. aureoviride (CEN222 and CEN206) were together in dendogram, CEN65 clustered next to $T$. viride. Anyway, morphological and cultural characteristics were adequately enough to characterize the isolate as $T$. aureoviride. Thus, RAPD analysis allowed detecting intraspecific variability of $T$. aureoviride and T. harzianum. In the group of T. harzianum, Brazilian isolates clustered at high similarity (>80\%), but three subclusters were found. 


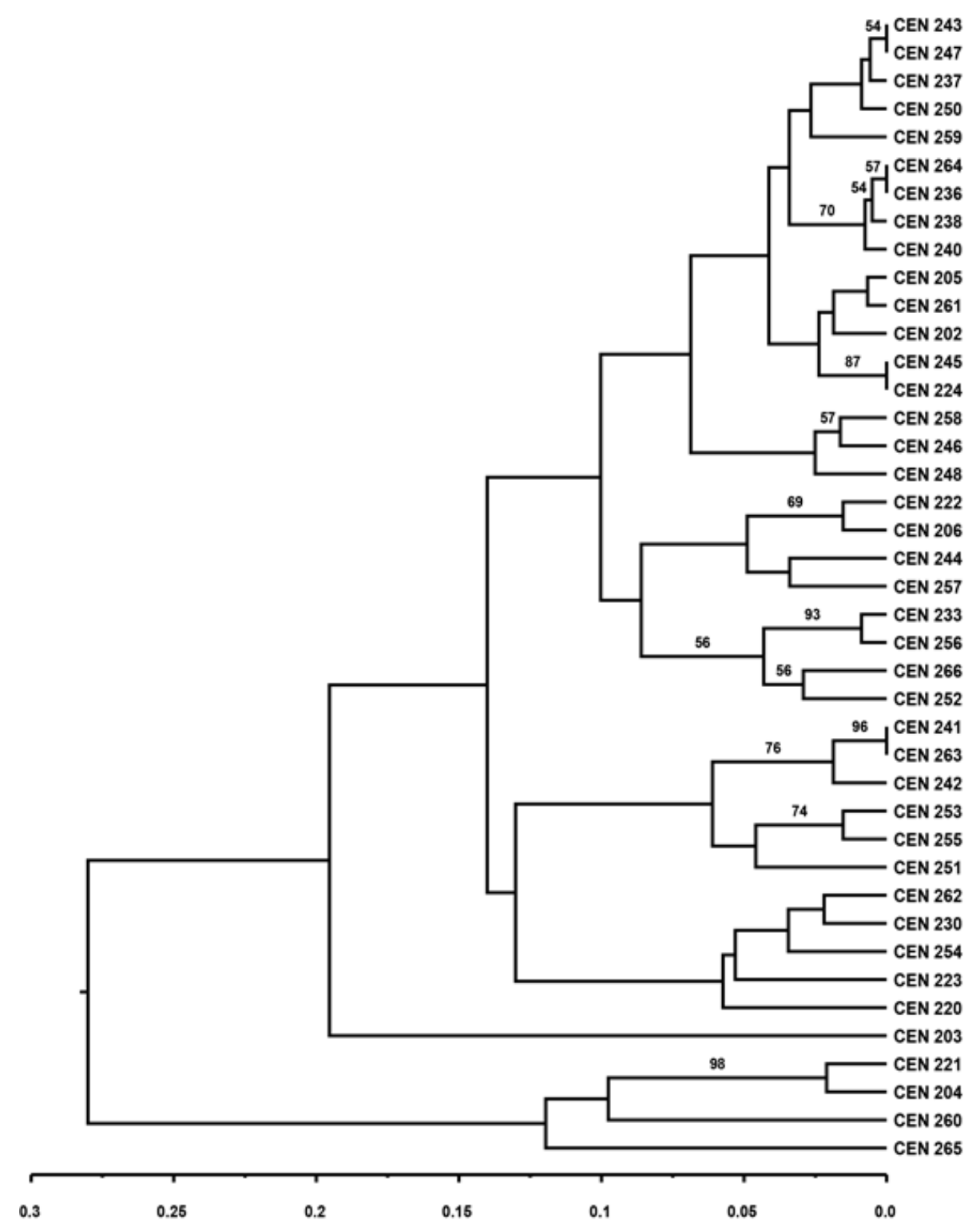

Figure 3. Intron splice site PCR unrooted UPGMA phylogram, based on a distance matrix calculated using the method of Nei and Li (1979). The scale represents branch length, and branch support (above branches; > 50\%) is given as a percentage of 1000 bootstrap replicates. T. crassum (CEN266 and CEN252), T. viride (CEN221, CEN204 and CEN260), T. aureoviride (CEN265, CEN222 and CEN206) and T. harzianum corresponds to the others isolates

\section{Discussion}

Colony appearance and growth rate have been considered as taxonomically useful characteristics for Trichoderma (Chaverri et al., 2003). However, these characteristics are frequently studied only on MEA and PDA (darkness). In this work, in addition to the above conditions, cultural characteristics of Trichoderma were also examined on OA to induce conidiation pustules. Also, fluorescent light (12 hours) was used in order to evaluate its effects on sporulation. On MEA, colony appearance of T. aureoviride was most similar to the reports published by Samuels et al. (2009). Differences in colonies grown of the same species on PDA could be verified when a fluorescent lamp was tested. Although $T$. viride and $T$. aureoviride exhibited indistinct sporulation, $T$. harzianum formed 3-4 concentric rings with dense conidial production when under light. No conidiation was verified in colonies of T. crassum on PDA (a). The behavior of this isolate was not repeated on PDA (b). Under light and on PDA, T. crassum exhibited characteristics described by Samuels et al. (2009), such as intensive conidiation bundled up in tiny pustules near the point of inoculation. A possible explanation for these results 
could be attributed to the light of fluorescent lamps inducing conidial production in some hyphomycetes (Carvalho et al., 2008). Moreover, typical yellow pigments verified in colonies of T. aureoviride when on PDA (b) and OA are not seen in dark-grown cultures (Samuels et al., 2009), confirming the importance of fluorescent light in the study of cultural characteristics of some Trichoderma species. OA medium is known for inducing conidiation pulverulence but this effect was observed only for T. crassum colonies (Figure 1).

T. harzianum and T. aureoviride grew more slowly than $T$. viride and T. crassum. Similar growth rates of $T$. harzianum on PDA and MEA under darkness with temperature of $25^{\circ} \mathrm{C}$ were also verified by Park et al. (2005), and in the same way, for T. aureoviride, by Samuels et al. (2009). A possible explanation for the fast growth rates verified for $T$. viride and T. crassum on all media tested could be attributed to specific characteristics of the respective isolates (CEN260 and CEN266), whose ability for in vitro growth was previously reported by Mello et al. (2007).

Although similar in shape, the $\mathrm{L} / \mathrm{W}$ ratio was a distinctive characteristic to establish difference between conidia of $T$. viride (L/W of 1.16) and T. aureoviride (L/W of 1.64), whose $\mathrm{L} / \mathrm{W}$ ratio are known to be around 1.0-1.2 and 1.4-1.8, respectively (Samuels et al., 2009). In spite of similar values in diameter, T. crassum $(3.8 \times 2.8 \mu \mathrm{m})$ and T. viride $(3.5 \times 2.9 \mu \mathrm{m})$ are not similar in shape and $\mathrm{L} / \mathrm{W}$ values. $T$. crassum presented typically ellipsoidal conidia with L/W ratio of 1.34, when it should be 1.3-1.4 (Chaverri et al., 2003).

The most common T. harzianum species showed a lower L/W ratio (2.23) of phialides (typically held in whorls of 2,3 or 4 ) than the others (2.92 to 3.86). It is also worth mentioning that $T$. harzianum from Brazilian conventional cotton crop soils appear to form phialides of a slightly shorter length than frequently verified for this specie. A similar result was verified by Park et al. (2005) in T. harzianum associated with green mold of oyster mushroom, whose phialides had a length of $5.4 \mu \mathrm{m}$. Concerning micromorphological characteristics, a significant variation in conidial morphology was initially reported for the T. viride aggregate (Bisset, 1991; Meyer \& Plaskowitz, 1989). Consequently, flexuous conidiophores and regularly paired branches and phialides (also verified in this study for CEN221, CEN204 and CEN260) were seen to be a distinctive characteristic for a great many isolates from this aggregate (Bisset, 1991). Phialides of T. aureoviride $(10.6 \times 2.8 \mu \mathrm{m})$ and $T$. crassum $(8.1 \times 2.9 \mu \mathrm{m})$ were significantly longer than those of the other two species. These characteristics are in accordance with reports from the literature. To exemplify, T. aureoviride can be characterized by its straight and tapering slightly from base to tip phialides, measuring 9.0-15.0 $\mu \mathrm{m}$ long and 2.5-3.9 $\mu \mathrm{m}$ wide in the middle (Samuels et al., 2009). Just as reported by Chaverri et al. (2003), T. crassum exhibited long unbranched conidiophores with one or few phialides at the tip. According to the previous author, this structure sometimes measures 200-300 $\mu \mathrm{m}$ long.

The RAPD data generated by amplification of genomic DNA of isolates of Trichoderma species suggested that there was interspecific variation among the isolates. Two isolates of T. aureoviride (CEN222 and CEN206) grouped in one cluster with 95\% similarity, except the isolate CEN265, which was grouped separately and showed around 35\% similarity with the other isolates of T. aureoviride. Kulling et al. (2000) reported that characterization of $T$. aureoviride is difficult. Although genetic variability were in a higher range (35-95\%), morphological and cultural characteristics presented were adequately enough to characterize this isolates as $T$. aureoviride.

Concerning to genetic variability of $T$. viride by RAPD markers, there are variable results in the literature. To exemplify, low similarity (around 55\%) among isolates of $T$. viride grouped in the same cluster was observed by Goes et al. (2002), while $82 \%$ of similarity was found by Shalini et al. (2006). Our results being between these two values, since the variability found among isolates was $70 \%$ (Figure 3). The isolates of T. crassum (CEN266 and CEN252) were clearly distinguished with the remaining isolates of Trichoderma spp. Analogously, Castle et al. (1998), in molecular studies, reported T. crassum isolates, producing unique RAPD patterns. T. harzianum produced three distinct subclusters, with $25 \%$ genetic distance among them. Within each subcluster, genetic similarity was high (85\%). Thus, results presented three possible different strains within T. harzianum complex. According to Shalini et al. (2006), T. harzianum is a species aggregate, grouped on the basis of conidiophores branching patterns with short side branches, short inflated phialides, and smooth and small conidia. T. harzianum has been divided in three, four, or five sub specific groups, depending on the strains and on the attributes considered (Grondona et al., 1997).

In accordance with Dubey and Soresh (2006), our results indicate RAPD technique as valuable to distinguish the isolates of Trichoderma according to their species with the help of specific primers. Specifically, primers used in this study were able to differentiate $T$. viride from other Trichoderma species. Restriction fragment length polymorphism of internal transcribed spacer (ITS) is also useful for strain identification, but RAPD is less time 
consuming and also suitable for interspecific differentiation (Zimand et al., 1994). Thus, the technique can be used for identification of specific species/strains.

Among four species studied, T. harzianum was the most common species in soils of conventional cotton crops $(80.6 \%)$, while the other species presented a low occurrence rate (7.3 and $4.8 \%)$. According to Bettucci and Roquebert (1995), the distribution of fungal species in soils of tropical countries is characterized by high frequency of few species (dominant) and a majority of species showing small number of isolates (singletons).

\section{Conclusion}

Finally, this work also showed the importance of establishing representative collections of Trichoderma spp., including isolates from the Brazilian Federal District, since potential antagonists are widespread in several distinct ecosystems in Brazil. Concerning the agricultural ecosystem evaluated, conventional cotton crops, four species of Trichoderma were identified, evidencing T. harzianum as the most common species. Moreover, the four species were morphologically distinguishable based on colony appearance, mycelium growth rate, shape of conidia, phialides and conidiophores and RAPD markers.

\section{References}

Almeida, A. M. R., Saraiva, O. F., Farias, J. R. B., Gaudêncio, C. A., \& Torres, E. (2001). Survival of pathogens on soybean debris under no-tillage and conventional tillage systems. Pesquisa Agropecuária Brasileira, 36, 1231-1238. https://doi.org/10.1590/S0100-204X2001001000003

Barros Lopes, M., Soden, A., Henschke, P. A., \& Langridge, P. (1996). PCR differentiation of commercial yeast strains using intron splice site primers. Applied and Environmental Microbiology, 62(12), 4514-4520.

Bettucci, L., \& Roquebert, M. F. (1995). Microfungi from a tropical rain forest litter and soil, a preliminary study. Nova Hedwigia, 61, 111-118.

Bissett, J. (1991). A revision of the genus Trichoderma. II. Infrageneric classification. Canadian Journal of Botany, 69(11), 2357-2372. https://doi.org/10.1139/b91-297

Carvalho, D. D. C., Alves, E., Batista, T. R. S., Camargos, R. B., \& Lopes, E. A. G. L. (2008). Comparison of methodologies for conidia production by Alternaria alternata from citrus. Brazilian Journal of Microbiology, 39(4), 792-798. https://doi.org/10.1590/S1517-83822008000400036

Carvalho, D. D. C., Geraldine, A. M., Lobo Junior, M., \& Mello, S. C. M. (2015). Biological control of white mold by Trichoderma harzianum in common bean under field conditions. Pesquisa Agropecuária Brasileira, 50(12), 1220-1224. https://doi.org/10.1590/S0100-204X2015001200012

Carvalho, D. D. C., Lobo Junior, M., Martins, I., Inglis, P. W., \& Mello, S. C. M. (2014). Biological control of Fusarium oxysporum f. sp. phaseoli by Trichoderma harzianum and its use for common bean seed treatment. Tropical Plant Pathology, 39(5), 384-391. https://doi.org/10.1590/S198256762014000500005

Castle, A., Speranzini, D., Rghei, N., Alm, G., Rinker, D., \& Bissett, J. (1998). Morphological and Molecular Identification of Trichoderma Isolates on North American Mushroom Farms. Applied and Environmental Microbiology, 64(1), 133-137.

Chaverri, P., Castlebury, L. A., Overton, B. E., \& Samuels, G. J. (2003). Hypocrea/Trichoderma: Species with conidiophore elongations and green conidia. Mycologia, 95(6), 1100-1140. https://doi.org/10.2307/3761915

Dhingra, O. D., \& Sinclair, J. B. (1981). Basic Plant Pathology Methods. CRC Press Inc., Boca Ratón, Florida.

Druzhinina, I., \& Kubicek, C. P. (2005). Species concepts and biodiversity in Trichoderma and Hypocrea: from aggregate species to species clusters? Journal of Zhejiang University Science, 6, 1200-112. https://doi.org/ 10.1631/jzus.2005.B0100

Dubey, S. C., \& Suresh, M. (2006). Randomly Amplified Polymorphic DNA Markers for Trichoderma species and Antagonism Against Fusarium oxysporum f.sp. ciceris Causing Chickpea Wilt. Journal of Phytopathology, 154, 663-669. https://doi.org/10.1111/j.1439-0434.2006.01167.x

Ethur, L. Z., Blume, E., Muniz, M. F. B., Antoniolli, Z. I., Nicolini, C., Milanesi, P., \& Fortes, F. O. (2008). Presença dos gêneros Trichoderma e Fusarium em solo rizosférico e não rizosférico cultivado com tomateiro e pepineiro, em horta e estufa. Ciência Rural, 38, 19-26. https://doi.org/10.1590/S0103-84782008 000100004

Felsenstein, J. (1985). Confidence limits on phylogenies: An approach using the bootstrap. Evolution, 39, 783-791. https://doi.org/10.1111/j.1558-5646.1985.tb00420.x 
Ferreira, D. F. (2011). Sisvar: A computer statistical analysis system. Ciência e Agrotecnologia, 35(6), 1039-1042. https://doi.org/10.1590/S1413-70542011000600001

Gajera, H. P., \& Vakharia, D. N. (2010). Molecular and biochemical characterization of Trichoderma isolates inhibiting a phytopathogenic fungi Aspergillus niger Van Tieghem. Physiological and Molecular Plant Pathology, 74(3), 274-282. https://doi.org/10.1016/j.pmpp.2010.04.005

Gams, W., \& Bisset, J. (1998). Morphology and Identification of Trichoderma. In C. P. Kubicek, \& G. E. Harman (Eds.), Trichoderma and Gliocladium (Vol. 1), Basic Biology, Taxonomy and Genetics (p. 324). Taylor \& Francis, Londres.

Góes, L. B., Costa, A. B. L., Freire, L. L. C., \& Oliveira, N. T. (2002). Randomly amplified polymorphic DNA of Trichoderma Isolates and antagonism against Rhizoctonia solani. Brazilian Archives of Biology and Technology, 45(2), 151-160. https://doi.org/10.1590/S1516-89132002000200005

Grondona, I., Hermosa, M. R., Tejada, M., Gomis, M. D., Mateos, P. F., Bridge, P., ... Garcýa Acha, I. (1997). Physiological and biochemical characterization of Trichoderma harzianum, a biological control agent against soilborne fungal plant pathogens. Applied Environmental Microbiology, 63(8), 3189-3198.

Inglis, P. W., Rubia, B. C., Sarmento, R. B. C., Gaviao, C. F. C., \& Valadares-Inglis, M. C. (2005). DNA fingerprinting of Paecilomyces strains of potential use for the biological control of pests. World Journal of Microbiology \& Biotechnology, 21, 1487-1492. https://doi.org/10.1007/s11274-005-7224-3

Kullnig, C., Szakacs, G., \& Kubicek, C. P. (2000). Molecular identification of Trichoderma species from Russia, Siberia and the Himalaya. Mycological Research, 104(9), 1117-1125. https://doi.org/10.1017/S095375620 0002604

Lisboa, B. B., Bochese, C. C., Vargas, L. K., Silveira, J. R. P., Radin, B., \& Oliveira, A. M. R. (2007). Eficiência de Trichoderma harzianum e Gliocladium viride na redução da incidência de Botrytis cinerea em tomateiro cultivado sob ambiente protegido. Ciência Rural, 37, 255-1260. https://doi.org/10.1590/S0103-8478200700 0500006

Mello, S. C. M., Ávila, Z. R., Braúna, L. M, Pádua, R. R., \& Gomes, D. (2007). Cepas de Trichoderma para el control biológico de Sclerotium rolfsii Sacc. Fitosanidad, 11, 3-9.

Meyer, R. J., \& Plaskowitz, J. S. (1989). Scanning electron microscopy of conidia and conidial matrix of Trichoderma. Mycologia, 81(2), 213-317. https://doi.org/10.2307/3759718

Nei, M., \& Li, W. H. (1979). Mathematical model for studying genetic variation in terms of restriction endonucleases. Proc. Natl. Acad. Sci. USA, 76, 5269-5273. https://doi.org/10.1073/pnas.76.10.5269

Pandya, J. R., Sabalpara, A. N., \& Mahatma, M. N. (2017). Randomly amplified polymorphic DNA analysis of native Trichoderma isolates. Asian Journal of Applied Science and Technology, 1(5), 147-150.

Park, M. S., Seo, G. S., Lee, K. H., Bae, K. S., \& Yu, S. H. (2005). Morphological and cultural characteristics of Trichoderma spp. associated with green mold of oyster mushroom in Korea. Plant Pathology Journal, 21, 221-228. https://doi.org/10.5423/PPJ.2005.21.3.221

Rai, S., Kashyap, P. L., Kumar, S., Srivastava, A. K., \& Ramteke, P. W. (2016). Identification, characterization and phylogenetic analysis of antifungal Trichoderma from tomato rhizosphere. Springerplus, 5(1), 1939. https://doi.org/10.1186/s40064-016-3657-4

Ranil, A. R., Ahammed, S. K., \& Patibanda, A. K. (2017). Genetic Diversity of Trichoderma sp. from rhizosphere regions of different cropping systems using RAPD markers. International Journal of Current Microbiology and Applied Sciences, 6(7), 1618-1624. https://doi.org/10.20546/ijcmas.2017.607.195

Rogers, S. O., \& Bendich, A. J. (1988). Extraction of DNA from plant tissues. In S. B. Gelvin, R. A. Schilperpoort \& D. P. S. Verma (Eds.), Plant Molecular Biology Manual (Vol. A6, pp. 1-10). Dordrecht: Kluwer Acadademic Publishers. https://doi.org/10.1007/978-94-017-5294-7_6

Samuels, G. J., Chaverri, P., Farr, D. F., \& McCray, E. B. (2009). Trichoderma Online, Systematic Mycology and Microbiology Laboratory, ARS, USDA. Retrieved from http://nt.ars-grin.gov/taxadescriptions/keys/ TrichodermaIndex.cfm

Shalini, Narayan, K. P., Nain, L., \& Kotasthane, A. S. (2006). Genetic relatedness among Trichoderma isolates inhibiting a pathogenic fungi Rhizoctonia solani. African Journal of Biotechnology, 5(8), 580-584. https://doi.org/10.5897/AJB05.379 
Shanmugam, V., \& Sharma, V., \& Ananthapadmanaban. (2008). Genetic Relatedness of Trichoderma Isolates Antagonistic against Fusarium oxysporum f.sp. dianthi Inflicting Carnation Wilt. Folia Microbiol, 53(2), 130-138. https://doi.org/10.1007/s12223-008-0019-9

Sharma, K., Mishra, A. K., \& Misra, R. S. (2009). Morphological, biochemical and molecular characterization of Trichoderma harzianum isolates for their efficacy as biocontrol agents. Journal of Phytopathology, 157, 51-56. https://doi.org/10.1111/j.1439-0434.2008.01451.x

Sneath, P. A., \& Sokal, R. R. (1973). Numerical Taxonomy. San Francisco: Freeman.

Swofford, D. L. (2003). PAUP*. Phylogenetic Analysis Using Parsimony (*and Other Methods) (Version 4). Sinauer Associates, Sunderland, Massachusetts.

Vinale, F., Sivasithamparam, K., Ghisalberti, E. L., Marra, R., Woo, S. L., \& Lorito, M. (2008). Trichoderma-plant-pathogen interactions. Soil Biology and Biochemistry, 40(1), 1-10. https://doi.org/ 10.1016/j.soilbio.2007.07.002

Zimand, G., Valinsky, L., Elad, Y., Chet, I., \& Manulis, S. (1994). Use of RAPD procedure for the identification of Trichoderma strains. Mycological Research, 98(5), 531-534. https://doi.org/10.1016/S0953-7562 (09)80474-7

\section{Copyrights}

Copyright for this article is retained by the author (s), with first publication rights granted to the journal.

This is an open-access article distributed under the terms and conditions of the Creative Commons Attribution license (http://creativecommons.org/licenses/by/4.0/). 